\title{
PEMBERLAKUAN PERDA SYARI'AH DALAM PERSPEKTIF SOSIOLOGI HUKUM ISLAM (Studi Kasus Penanggulangan Eksploitasi Seks Komersial di Surakarta)
}

\author{
Mudzakir \\ Institut Agama Islam Negeri Kudus \\ Email:mundakir@iainkudus.ac.id
}

\begin{abstract}
This paper raises the issue of whether the enactment of Islamic Sharia in Indonesia should be a form of law and/or local regulation that binds the community (formalization of Islamic law) or is sufficiently enforced persuasively. This research takes the object of surakarta people who have enacted the Surakarta City Regional Regulation Number 3 of 2006 on Tackling Commercial Sexual Exploitation. Formil the regulation of this area does not mention the word sharia but the substance of the material stipulated in the regulation is entirely sharia material or figh. The existence of this government is acceptable to all elements of Surakarta people who have a background and a hiterogen religion. With grounded research and participatory observational data collection techniques, researchers found evidence that Surakarta people fail to cope with the rise of prostitution and commercial sexual exploitation persuasively, they require government involvement (formalization of Islamic law). By looking at the religious characteristics of Surakarta people whose religion is not so strong, the formalization of Islamic law into local regulations finds its significance. For areas where religion is strong enough, the enactment of Islamic Sharia is sufficient with a persuasive pattern based on the religious awareness of the community.
\end{abstract}

Keywords: Formalization of Islamic Law, Characteristics, Awareness of Religion

\begin{abstract}
Abstrak
Paper ini mengangkat permasalahan apakah pemberlakuan Syari'ah Islam di Indonesia perlu menjadi suatu bentuk undang-undangdan/atau peraturan daerah yang mengikat masyarakat (formalisasi hukum Islam) atau cukup diberlakukan secara persuasif. Penelitian ini mengambil obyek masyarakat Kota Surakarta yang telah memberlakukan Peraturan Daerah Kota Surakarta Nomor 3 Tahun 2006 tentang Penanggulangan Eksploitasi Seksual Komersial. Secara formil peraturan daerah ini tidak menyebut kata syari'ah tetapi substansi materi yang diatur dalam perda tersebut sepenuhnya materi syari'ah atau fiqh. Keberadaan perda ini dapat diterima oleh seluruh elemen masyarakat Kota Surakarta yang memiliki latarbelakang dan pemeluk agama yang hiterogen. Dengan grounded research dan teknik pengumpulan data observasi partisipatoris, peneliti menemukan bukti bahwa masyarakat Kota Surakarta gagal menanggulangi maraknya prostitusi dan eksploitasi seks komersial secara persuasif, mereka membutuhkan keterlibatan pemerintah (formalisasi hukum
\end{abstract}


Islam). Dengan mencermati karakteristik keberagamaan masyarakat Kota Surakarta yang keberagamaannya tidak begitu kuat, formalisasi hukum Islam menjadi peraturan daerah menemukan signifikansinya. Untuk wilayah-wilayah yang keberagamaannya cukup kuat, pemberlakuan syariah Islam pada cukup dengan pola persuasif yang didasarkan atas kesadaran beragama masyarakat.

Kata Kunci: Formalisasi Hukum Islam, Karakteristik, Kesadaran Keberagamaan

\section{PENDAHULUAN}

Penelitian tentang dampak prostitusi dan eksploitasi seks komersial sudah banyak dilakukan, diantaranya oleh Hamdan dengan judul Dampak Prostitusi Liar Terhadap Kehidupan Sosial Masyarakat Desa Sekolaq Muliaq, Kecamatan Sekolaq Darat, Kabupaten Kutai Barat. Penelitian deskriptif ini menggambarkan bahwa prostitusi liar di Desa Sekolaq Muliaq memantik meningkatnya kriminalitas, menganggu ketenteraman masyarakat, mengakibatkan sering terjadinya perkelahian dalam rumah tangga dan meningkatnya kasus perceraian serta terganggunya perkembangan mental anak-anak yang hidup di sekitar area prostitusi liar (Hamdan, 2012).

Prostitusi tergolong masalah sosial yang sampai saat ini asal mulanya tidak dapat diketahui secara pasti, sekalipun banyak anggota masyarakat yang tidak menghendaki adanya prostitusi, namun praktiknya terus terjadi baik secara sembunyi-sembunyi maupun secara terang-terangan. Para pelaku yang terlibat tidak semuanya bisa dijerat oleh hukum pidana, hanya mucikari atau penyedia tempat yang dapat dijerat hukum pidana (Sularto, 2019). Munculnya ragam tipologi pelacuran, faktor-faktor yang mempengaruhi berkembangnya pelacuran telah menambah kompleksitas masalah dalam menangani dan menjadi semakin sulit untuk direhabilitasi, dipaparkan oleh Binahayati Rusyidi dan Nunung Nurwati dari hasil penelitiannya dengan judul Penanganan Pekerja Seks Komersial di Indonesia (Rusyidi, 2018).

Praktik prostitusi yang terungkap ternyata pelaku dan korbannya rata-rata adalah para wanita muda atau remaja putri berusia di bawah umur. Sekalipun tidak bisa digeneralisasi, misalnya prostitusi di Apartemen Kalibata City, salah satu korbannya adalah perempuan yang hamil enam bulan yang diduga hamil akibat dari praktik prostitusi. Meskipun hamil, korban tetap disuruh untuk melayani pria hidung belang oleh mucikari. Bahkan korban melayani dua hingga tiga pria per harinya (http://ecpatindonesia.org/berita/bersama-wujudkan-internetramah-anak, diakses 29 September 2015). Walikota Surabaya, ketika akan menutup lokalisasi Dolly, mendapatkan seorang anak perempuan berumur 8 tahun menjadi pelacur dan mempunyai banyak pelanggan (Augusmi, et al, 2014). Anak yang seharusnya mendapatkan pendidikan dan perlindungan orang tua, justru mengalami kisah hidup yang sangat memprihatinkan (Yanto, 2016). 
Di Indonesia strategi penanganan kurban prostitusi didominasi pola pendekatan rehabilitasi terhadap pekerja seks namun belum sepenuhnya sejalan dengan prinsip-prinsip rehabilitasi (Rusyidi \& Nurwati, 2018), dan belum banyak menyentuh bagaimana menanggulangi dan menangani kurban prostitusi dan seks komersial yang terdiri dari perempuan dan anak-anak (Mudzakir, 2013). Dari hasil penelusuran, peneliti menemukan peraturan daerah yang menyentuh kedua entitas tersebut dalam menanggulangi maraknya prostitusi dan seks komersial yaitu Peraturan Daerah Kota Surakarta Nomor 3 Tahun 2006 tentang Penanggulangan Eksploitasi Seks Komersial di Kota Surakarta.

Namun demikian, tulisan singkat ini tidak menguraikan hal-hal yang menjadi perhatian para peneliti mengenai maraknya prostitusi dan eksploitasi seks komersial serta bagaimana menangani para kurban dari kedua kegiatan tersebut. Penelitian yang penulis lakukan lebih fokus pada masalah bentuk penegakan tatanan sosial seperti penanganan maraknya prostitusi dan eksploitasi seks komersial. Apakah diperlukan pendekatan represif dalam bentuk regulasi formal seperti undang-undang dan/atau peraturan daerah atau cukup dengan pendekatan persuasif melalui nasehat-nasehat religius, karena obyek masalahnya menyangkut materi hukum Islam.

\section{METODE PENELITIAN}

Paper ini termasuk dalam jenis penelitian lapangan (field research) yaitu penelitian dengan mengambil data primer dari lapangan, daerah atau lokasi (locus) tertentu (Sugono, 2003), atau dengan mengkaji ketentuan hukum yang berlaku serta apa yang terjadi dalam kenyataan di masyarakat (Waluyo, 2002). Metode pendekatan yang digunakan dalam kajian paper ini adalah yuridis sosiologis. Maksud dari pendekatan yuridis sosiologis ialah mengidentifikasi dan mengkonsepsikan hukum sebagai institusi sosial yang nyata dan fungsional dalam sistem kehidupan yang riil. Pendekatan ini bertujuan untuk memperoleh pengetahuan hukum secara empiris dengan melakukan terjun ke lapangan yakni mengetahui pemberlakuan perda syariah sebagai upaya penanggulangan eksploitasi seks komersial di Kota Surakarta ditinjau dari Sosiologi Hukum Islam.

Sumber data yang digunakan dalam paper ini adalah data primer dan data sekunder. Data primer berupa hasil wawancara dari para informan, sedangkan data sekunder berupa peraturan perundangundangan seperti Peraturan Daerah Kota Surakarta Nomor 3 Tahun 2006 tentang Penanggulangan Eksploitasi Seksual Komersial, buku-buku, artikel jurnal dan lain-lain. Teknik pengumpulan data menggunakan studi kepustakaan, observasi, dan wawancara. Sementara itu, metode analisis data yang digunakan adalah diskriptif kualitatif yaitu suatu cara untuk menggambarkan dan mengintepretasikan data-data yang telah 
dikumpulkan, sehingga diperoleh gambaran secara menyeluruh terkait keadaan sebenarnya.

\section{PEMBAHASAN}

\section{Sosio-Religius Masyarakat Kota Surakarta}

Deskripsi tentang kondisi sosial keberagamaan masyarakat Kota Surakarta berikut menggunakan pendekatan lebih spesifik, dan sekedar membuat sketsa (Perera, 1990: xvii). Deskripsi singkat tersebut dimaksudkan untuk mengetahui latar belakang lahirnya tatanan sosial berupa peraturan daerah sebagai hasil konstruksi sosial dalam konteks sosio-religius dan kultural masyarakat Kota Surakarta untuk menanggulangi maraknya prostitusi dan eksploitasi seks komersial.

Lahirnya peraturan daerah sebagai salah satu bentuk budaya masyarakat, jika hanya dideskripsikan melalui pendekatan legal-formal sebagai produk hukum tidak akan mampu menelusuri dasar pengetahuan dan karakteristik sosio-religius masyarakat dalam mengkonstruksi tatanan sosial itu (Berger, 1994: 7-10). Terlebih materi peeraturan daerah tersebut bersentuhan dengan persoalan ajaran agama Islamyang telah berkelindan dengan pengetahuan keberagamaan masyarakat itu.

Di samping Yogyakarta, Kota Surakarta merupakan salah satu sentral budaya Jawa (Mulder, 2001: 2), memiliki karakteristik budaya Jawa (kejawen). Ketika Islam masuk ke wilayah nusantara pada abad ke-7 atau 13, bertemu dan berinteraksi dengan berbagai penganut paham dan kepercayaan yang ada (Syam, 2005: 63-67), terdapat dimensi yang bisa bersenyawa (sinkritis), ada yang mengalami penyesuaian (akulturasi) dengan keberagamaan dan tradisi yang dianut masyarakat Jawa (Abdullah, 1996: 5).

Karakteristik keberagamaan masyarakat Jawa terbentuk melalui dasar pengetahuan Islam yang dibawa oleh para penyebar Islam di wilayah nusantara melalui jalur perdagangan (Syam, 2005: 63-64), yang lebih bercorak legal formal (syari'ah Islam). Tetapi tidak sedikit yang berpendapat bahwa penyebaran Islam di wilayah nusantara dilakukan oleh para da'i sufi, yang berimplikasi pada wujud keberagamaan masyarakat yang bernuansa sufistik.

Di antara ahli sejarah yang mendukung pola pertama, mereka mengangkat bukti-bukti hasil perdagangan seperti rempah-rempah di wilayah India Selatan, khususnya Kerala dan Asia Selatan (Malabar) dan Asia Timur (Koromandel) yang masyarakatnya lebih dahulu memeluk Islam. Sementara yang mendukung pola kedua, mengangkat bukti-bukti tersebarnya ajaran Islam demikian cepat dan mendapatkan respon demikian luas (Noer, 1996: xi). Analisis terjadinya respon demikian cepat itu antara lain karena kemampuan para da'i sufi mengadopsi tradisi lokal menjadi bagian keberagamaan Islam (Syam, 2005: 64). 
Ketika para penyebar Islam berinteraksi dengan orang-orang Jawa yang telah memeluk sejumlah kepercayaan, maka dimulai islamisasi tradisi dan terbentuk keberagamaan khas. Sebagai pusat budaya Jawa, masyarakat Kota Surakarta memiliki karakteristik tradisi dan budaya yang berpusat di Keraton Surakarta, dengan pujangga terakhirnya R. Ng. Ronggowarsito (Endraswara, 2004: 23-24). Mereka menyambut kedatangan Islam yang tradisi dan budayanya dalam beberapa dimensi memiliki harmoni entitas ajaran (Syam, 2005: 2-4). Sebagai pusat perdagangan batik, masyarakat Surakarta juga menyambut kedatangan para pedagang, baik para pedagang yang murni beretujuan dagang maupun para pedagang yang membawa misi penyebaran Islam.

Keberhasilan para penyebar Islam di nusantara khususnya di wilayah Keraton Surakarta, terlihat pada prosentase pemeluk agama Islam pada tahun 2010 cukup besar, yaitu 72\% atau kira-kira 359.427 orang dari 499.205 jumlah penduduk (Bagian Administrasi Kesra Setda Kota Surakarta, 2010) Pada tahun 2019 ini pemeluk Islam mencapai450 392orang dari 572.560 jumlah penduduk (Badan Pusat Statistik Kota Surakarta, 2010). Dengan menganalisis interaksi muatan ajaran Islam yang disebar-luaskan di wilayah Jawa khususnya di Surakarta terdapat ragam tipologi pemeluk keberagamaan. Masing-masing tipologi memiliki karakteristik tersendiri dan dapat diidentifikasi menjadi pemeluk Islam modernis, pemeluk Islam tradisionalis, dan pemeluk Islam kejawen dan belakangan muncul pemeluk Islam radikalis.

Tipologi keberagamaan masyarakat Kota Surakarta ini (Berger \& Luckman, 1990: 44), didasarkan pada karakteristik pengetahuan keberagamaan Islam yang tereksternalisasi menjadi kehidupan bermasyarakat di tengah kehidupan tradisi kejawen, khususnya dimensi mistik Jawa (Syam, 2005: 4-5). Penulis sadar bahwa karakterisasi keberagamaan masyarakat menjadi empat tipologi pemeluk ajaran Islam tersebut tidak terlalu tepatetapi diperlukan untuk:

Pertama, mengetahui tingkat refleksi subyektif keberagamaan atau tingkat keresahan masing-masing kelompok atas maraknya eksploitasi seks komersial di Kota Surakarta, yang oleh sebagian masyarakat dikaitkan dengan dimensi mistik, relegi dan dimensi sosial lainnya. Disadari bahwa terwujudnya tatanan sosial merupakan proses eksternalisasi dari dunia intersubyektif pada individu dan masyarakat memiliki variasi.

Kedua, untuk mengetahui bentuk obyektivasi norma masingmasing kelompok dalam proses institusionalisasi atau bentuk tatanan sosial obyektif sebagai institusi (peraturan daerah) yang dianggap bisa menyelesaikan persoalan masyarakat pada masing-masing kelompok. Bentuk institusi yang dianggap bisa menyelesaikan permasalahan masyarakat juga tidak selalu sama pada masing-masing tipologi keberagamaan. Oleh karena itu diperlukan menarik benang merah 
(universalitas) norma yang bisa diterima oleh masing-masing institusi sosial itu.

\section{Maraknya Prostitusi dan Eksploitasi Seks Komersial di Surakarta.}

Definisi dan cakupan pengertian prostitusi atau pelacuran akan terus berkembang beserta faktor-faktor penyebab maraknya,seiring dengan perkembangan budaya manusia. Fenomena maraknya prostitusi dan eksploitasi seks komersial menjadi keprihatinan sebagian besar masyarakat yang memandang hal tersebut telah nyata menimbulkan kerusakan moral masyarakat (madarrah), terutama setelah bergesernya prostitusi sebagai bisnis dan tercipta mekanisme pasar. Terdapat pihakpihak yang memasok kepada yang membutuhkan (supply-demands) menjadikan pelacuran sebagai perilaku yang sulit diberantas (Naskah Akademik Rancangan Peraturan Daerah Kota Surakarta).

Kesulitan tersebut karena oleh sebagian orang, di samping diposisikan untuk memenuhi kebutuhan biologis, prostitusi juga untuk memenuhi kebutuhan ekonomis, sosiologis, psikologis dan kultural (Hadi \& Triantoro, 2001: 281). Dari faktor ekonomi pada umumnya lebih dikarenakan alasan himpitan ekonomi masyarakat dan kerasnya persaingan usaha, pelacuran oleh sebagian yang lain dijadikan sebagai usaha atau kerja untuk memperoleh penghasilan. Untuk memenuhi kebutuhan dasar manusia (basic need) setiap orang memiliki cara dan nasib yang berbeda-beda. Sebagian masyarakat melakukan prostitusi dikaitkan dengan kepercayaan masyarakat (Danusiri, 2012), terlepas dari etika dan norma yang membatasi cara-cara pemenuhan kebutuhan dasar manusia tersebut.

Dari faktor sosiologis lebih didasarkan kepada ketidak-seimbangan pembangunan di kota dan di desa menyebabkan terjadinya migrasi dari desa ke kota yang tidak dibarengi dengan keterampilan memadai, kesenjangan antara kelompok menengah ke atas dengan kelompok menengah ke bawah (Wawancara dengan Juni Wahjono, Tokoh Agama Khatolik dan Ketua Pansus Perda Nomor 3 Tahun 2006, 19 Januari 2012). Gaya hidup di tengah gemerlapnya kehidupan kota, mendorong seseorang untuk mencari pekerjaan yang mudah dan instan untuk mendapatkan uang. Perkembangan teknologi dan komunikasi di dunia maya menjadi media transaksi sangat mudah berkembangnya prostitusi dan eksploitasi seks, meluasnya jaringan beserta variasinya (Wawancara dengan Renny Widyawati, Anggota DPRD Kota Surakata, 19 Januari 2012).

Sementara itu dampak yang menimpa para korban maraknya prostitusi dan eksploitasi perempuan lebihdidominasi adanya perdagangan perempuan dan anak-anak yang dikenal dengan trafficing. Para korban ini rata-rata adalah perempuan yang lemah secara ekonomi dan kurang memiliki keterampilan. Rendahnya pendidikan dan ada 
dalam kekuasaan para mafia, mereka tidak memiliki pilihan kecuali menyerahkan diri. Disharmoni keluarga dan kurangnya perhatian orang tua terhadap anak (Wawancara dengan Juni Wahjono, Tokoh Agama Khatolik dan Ketua Pansus Perda Nomor 3 Tahun 2006, 19 Januari 2012), menjadikan kehidupan anak yang masih labil dalam menghadapi berbagai kenyataan dalam masyarakat, tanpa panduan hidup yang memadai. Hal ini menjadi salah satu faktor psikis yang memicu berkembangnya trafficing di kota-kota besar seperti di Surakarta (Wawancara dengan Renny Widyawati, Anggota DPRD Kota Surakata, 19 Januari 2012).

Dalam perspektif teologis, karena lemahnya iman umat beragma, keroposnya ideologi dan rapuhnya akidah, menjadi penyebab dominan maraknya prostitusi di berbagai daerah (Wawancara dengan Syamsuddin Dahlan, Tokoh Agama Islam Kota Surakarta, 18 Januari 2012). Bila dicermati lebih seksama, mereka yang melanggar hukum agama dan norma-norma sosial di masyarakat, bukan berarti tidak dapat membedakan antara baik dan buruk, larangan dan perintah, boleh tidak boleh, tetapi lebih disebabkan adanya kepribadian yang lemah sehingga mudah terpengaruh kehidupan kota dan desakan ekonomi di samping pendidikan yang kurang memadai. Faktor-faktor tersebut menambah peningkatan jumlah wanita tuna susila (WTS) dan para penggunanya yang semakin mengkhawatirkan.

Di kota besar seperti Surakarta pada saat ini, prostitusi telah berkembang menjadi industri seks. Para pelacur menjadikan dunia pelacuran sebagai lapangan kerja (Wawancara dengan Juni Wahyono, Tokoh Agama Khatolik dan Ketua Pansus Perda Nomor 3 Tahun 2006, 18 Januari 2012), dan dapat digolongkan dalam dua kategori yaitu mereka yang melakukan prostitusi dengan sadar dan sengaja berdasarkan motivasi tertentu (ekonomi atau memburu kesenangan) dan mereka yang melakukannya karena terpaksa (ekonomi, ditawan atau dijebak oleh germo, calodan pengusaha bordil) (Wawancara dengan Sudiro (Nama Samaran), Pemilik Rumah Bordil di Wilayah RRI Kota Surakarta, 23 Pebruari 2012).

Pelacuran telah berkembang sebagai komoditas yang diwujudkan oleh sebagian kelompok masyarakat menjadi praktik secara langsung maupun tidak langsung memperoleh keuntungan (Wawancara dengan Syamsuddin Dahlan, Tokoh Agama Islam Kota Surakarta, 18 Januari 2012). Mereka itu antara lain para mucikari, pemilik rumah bordil, pemilik dan pekerja di tempat panti pijat dan bar, penjual makanan dan minuman di sekitar lokasi, para petugas keamanan termasuk polisi, sopir taksi, tukang ojek dan pengemudi becak yang berfungsi sebagai penghubung antara wanita pekerja seks komersial dengan calon pengguna jasa seks.

Surakarta sebagai kota transit perdagangan perempuan dan anakanak (trafficing) untuk kepentingan prostitusi telah berlangsung lama. 
Disebut sebagai kota transit, karena Kota Surakarta seringkali dijadikan tempat penampungan sementara pasokan dari daerah sekitar untuk memenuhi kebutuhan daerah lain dan kebutuhan dari luar negeri. Banyaknya pasokan dari luar daerah, seringkali mengalami stok berlebih karena mengalami kendala pengiriman, mereka terpaksa tinggal dan dijajakan di Kota Surakarta (Wawancara dengan Renny Widayati, Anggota DPRD Kota Surakarta, 28 Januari 2012).

Ada banyak ragam tentang latar belakang seseorang melakukan prostitusi, alasan yang paling klasik adalah karena desakan ekonomi (Wawancara dengan Ahmad Zain Solichul Hadi, Kepala Bidang Data dan Pelaporan BAPPEDA Kota Surakarta, 17 Januari 2012). Namun setelah merasakan mudahnya mengumpulkan rupiah dengan melakukan prostitusi, mereka cenderung meneruskan pekerjaan itu. Tidak sedikit perempuan yang menjajakan diri tidak dalam pengertian dieksploitir atau karena terpaksa, tetapi sengaja untuk mencari penghasilan dengan melakukan prostitusi. Prostitusi telah menjadi fenomena sosial yang menjadi faktor pendukung maraknya hiburan dan kesenangan (sex tourism) yang ditawarkan di Kota Surakarta. Di kota-kota wisata seperti Surakarta, sebagian touris sekaligus memanfaatkan seks sebagai bagianhiburan dan kesenangan dari daerah lain. Keadaan ini dijadikan sasaran perempuan yang ingin menjajakan diri dari daerah sekitarnya.

Bentuk dan mekanisme serta pola pelayanan yang ditawarkan industri seks juga menjadi semakin beragam. Keragaman ini berkembang seiring dengan kebutuhan industri seks, baik yang terorganisasi, seperti lokalisasi, panti pijat, rumah bordil, klub malam, salon kecantikan, dan diskotik, maupun yang tidak terorganisasi dan dapat ditemukan pada beberapa kelompok wanita panggilan maupun wanita penghibur jalanan dari pasaran kelas menengah sampai kelas bawah (Wawancara dengan Muhammad Radli, Anggota DPRD Kota Surakarta, 16 Januari 2012).

Perkembangan praktik prostitusi, selain bertentangan dengan norma agama dan sosial, dapat pula menimbulkan kecenderungan meningkatnya penyakit menular seksual di masyarakat. Penyakit ini merusak mentalitas terutama dari kalangan generasi muda yang rentan terhadap akses negatif dari adanya praktik pelacuran. Meluasnya industri seks, mengakibatkan banyak anak-anak dan perempuan yang dipaksa untuk menjadi pekerja seks komersial (Wawancara dengan Juni Wahjono, Tokoh Agama Khatolik dan Ketua Pansus Perda Nomor 3 Tahun 2006, 19 Januari 2012).

Prostitusi pada anak-anak merupakan salah satu dari bentuk pekerjaan terburuk bagi anak dan merupakan pelanggaran mendasar hakhak atas anak. Tekanan fisik dan emosi yang dialami oleh korban prostitusi anak memiliki akibat serius pada hak anak untuk tumbuh dan berkembang dengan wajar. Selain itu, anak korban prostitusi rentan terhadap berbagai penyakit, khususnya yang ditularkan melalui 
hubungan seks dengan segala akibatnya. Resiko lain yang dipikul anak korban prostitusi, berupa penolakan dalam kehidupan sosial dan kemungkinan menjadi korban kekerasan (Naskah Akademik Rancangan Peraturan Daerah Kota Surakarta).

Keberadaan anak-anak yang dilacurkan di Indonesia sudah disadari sejak lama oleh berbagai pihak. Irwanto dan kawan-kawan mensinyalir, pada tahun 1999 di suatu pusat rehabilitasi perempuan di Jakarta Utara, sedikitnya 5\% (lima persen) dari 2.750 pekerja seks berusia kurang dari 15 tahun (Irwanto \& Anwar, 1999: 15). Menurut catatan Surabaya Post tanggal 5 April 2000, jumlah anak perempuan yang dilacurkan telah mencapai 40-70 ribu orang. Muhammad Farid memprediksi, sekitar 30 persen dari total pekerja seks di Indonesia adalah anak-anak di bawah umur 18 tahun (Suyanto \& Haria, 2002: 55). Data Kepolisian Republik Indonesia pada tahun 2000 mencatat jumlah kasus perdagangan anak yang dilaporkan lebih dari 1.400 kasus belum lagi yang tidak dilaporkan atau tidak diketahui. Setiap kasus bisa melibatkan dua hingga sepuluh korban perempuan dan sebagian besar anak-anak (Harian Kompas, 2001: 2).

Data Bareskrim Polri dari tahun 2011 hingga 2013 yang dilansir KPAI (Komisi Perlindungan Anak Indonesia) menyebutkan bahwa eksploitasi seks komersial anak (ESKA) menduduki kasus eksploitasi terbesar, dengan jumlah kasus sebesar 205. Salah satu kasus eksploitasi seksual terhadap anak ini adalah kasus perdagangan (trafficking) anak. Kasus perdagangan anak ini mengalami peningkatan setiap tahunnya (Kartikawati, 2014).

Lebih jauh dalam Konvensi International Labour Organization (ILO) No. 182 dinyatakan prostitusi anak tergolong pekerjaan yang berbahaya bagi anak. Dalam konvensi hak anak secara tegas digariskan, anak yang dilacurkan merupakan salah satu pelanggaran hak yang sangat mendasar (Naskah Akademik Rancangan Peraturan Daerah Kota Surakarta). Hal demikian disebabkan karena perlakuan terhadap anak yang dilacurkan, baik secara fisik maupun emosional, sangat mengganggu hak tumbuh-kembang anak (Rezki, et al., 2014).

Bentuk perlakuan tersebut antara lain perlakuan kasar, tidak dipenuhi hak pendidikannya, diskriminasi, eksploitasi secara ekonomi dan seringkali diperjualbelikan atau dicabut dari lingkungan rumah mereka secara paksa (Mudzakir, 2013). Selain itu mereka juga mendapatkan stigma sosial dengan kondisi yang mereka alami, mereka bisa terjangkit berbagai penyakit terutama penyakit menular seksual (PMS) dengan seluruh implikasinya. Penderitaan psikologis sebagai akibat penolakan atau bahkan isolasi dari masyarakat serta akibat tindak kekerasan yang diperoleh dari germo maupun tamu di saat bekerja dirasakan terlalu berat bagi anak-anak (Ramdhany, 2013: 2). 
Penelitian yang dilakukan International Labour Organization (ILO), Yayasan Kusuma Buana, Pusat Kajian Pembangunan Atmajaya dan Universitas Airlangga pada tahun 1998 melalui studi kasus anak yang dilacurkan melaporkan bahwa kehidupan sehari-hari dalam kehidupan remang-remang di beberapa tempat di Indramayu seperti di Kecamatan Bongas dan Kecamatan Kandanghaur banyak menemukan anak-anak baik yang secara langsung maupun tidak langsung terlibat dalam kehidupan remang-remang itu.

Penelitian Yayasan Kakak pada tahun 2000 berhasil menjangkau tidak kurang dari 50 anak yang dilacurkan tersebar di lima dari tujuh daerah tingkat II di wilayah eks Karesidenan Surakarta dan mayoritas (28 anak) berasal dari Kota Surakarta. Sedangkan selama pendampingan periode tahun 2001 sampai dengan tahun 2004 yang menjangkau 65 anak yang dilacurkan, terdiri dari $69 \%$ berasal dari Kota Surakarta. Dari data yang diperoleh dari dampingan Yayasan Kakak, menunjukkan bahwa 90\% dari mereka pernah menjadi korban perdagangan untuk tujuan seksual. Hasil penelitian tersebut menunjukkan bahwa Kota Surakarta termasuk daerah pengirim, transit dan penerima perdagangan anak untuk tujuan seksual (Naskah Akademik Rancangan Peraturan Daerah Kota Surakarta).

Para pelaku eksploitasi seks komersial (ESK) yang dimaksud di sini adalah germo atau mucikari, peranatara, pengguna jasa seks, jasa keamanan, penyedia fasilitas atau tempat untuk kegiatan seks komersial. Sedangkan tempat-tempat kegiatan seks komersial misalnya seperti hotel, salon, panti pijat, rumah penduduk, kafe atau musro, kios dan lain-lain yang dengan sengaja mengadakan atau memudahkan perbuatan cabul. Sedangkan korbannya adalah anak-anak (seseorang yang berusia di bawah usia 18 tahun) dan perempuan di atas usia 18 tahun.

Termasuk salah satu faktor yang turut berperan meningkatnya permintaan anak yang dilacurkan adalah adanya anggapan atau mitos oleh sebagian masyarakat, bahwa melakukan hubungan seks dengan anak akan membuat pelakunya awet muda. Selain itu ketakutan akan terkena HIV atau AIDS membuat konsumen mencari obyek seksual baru yang dianggap lebih aman dari resiko, yaitu anak-anak. Terdapatnya jaringan kriminal yang mengorganisasi insdustri seks dan rekrutmen anak, menambah suburnya prostitusi di Kota Surakarta (Naskah Akademik Rancangan Peraturan Daerah Kota Surakarta).

Pola rekrutmen terhadap para pelajar atau siswi SLTA dan mahasiswi, mendapatkan momentum yang baik seiring dengan gaya hidup remaja (Wawancara dengan Juni Wahjono, Tokoh Agama Khatolik dan Ketua Pansus Perda Nomor 3 Tahun 2006, 19 Januari 2012). Bahkan PPK UNS menemukan hubungan signifikan antara suburnya prostitusi dengan meningkatnya keadaan keluarga tidak harmonis, pembiaran terhadap urusan anak, penelantaran anak, kemiskinan keluarga, 
Pemberlakuan Perda Syari'ah dalam Perspektif....

minimnya akses untuk pelayanan sosial dan hubungan seksual usia dini (UNICEF \& PPK UNS, 2004: 25).

\section{Penanggulanan Maḍarrah-nya Prostitusi dan Eksploitasi Seks Komersial}

Prostitusi atau pelacuran merupakan perbuatan yang seusia dengan peradaban manusia dan terus berkembang mengiringi perkembangan budaya manusia. Hubungan kelamin merupakan kegiatan yang bermuara dari kebutuhan dasar (fitrah) manusia dewasa (Jalaluddin, 2005: 87), sebagaimana kebutuhan dasar lainnya seperti sandang, pangan dan papan. Karenanya Allāh swt memberikan tuntunan kepada manusia untuk memenuhi kebutuhan dasar itu, dan membuat tuntutan terhadap orang yang melanggar kebutuhan dasar tersebut.

Para pemuka agama telah memberikan pencerahan kepada masyarakat secara persuasif supaya menyalurkan kebutuhan dasar manusia itu melalui jalan yang telah ditentukan dalam kitab suci masingmasing agama (Wawancara dengan Juni Wahjono, Tokoh Agama Khatolik dan Ketua Pansus Perda Nomor 3 Tahun 2006, 19 Januari 2012). Sekalipun di dalam al-Qur'ān hanya melarang perzinaan dan tidak ada ayat yang menyebutkan larangan pelacuran tetapi Islam melarang adanya pelacuran. Pelacuran mempunyai cakupan pengertian berbeda dengan zina, semua pelacuran dengan segala bentuk, sifat dan frekuensinya adalah zina (Miyatun, 2006: 5).

Pengertian perzinaan lebih sempit daripada pelacuran dan sanksi yang dijatuhkan kepada orang yang melakukan perzinaan, menurut sūrah Al-Nūr (24): 2 adalah dijilid.

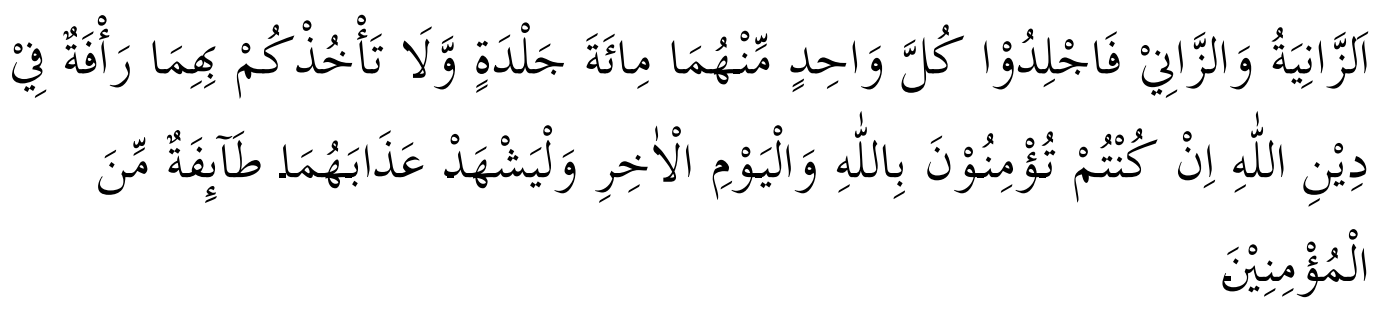

Artinya: "Pezina perempuan dan pezina laki-laki deralah masing-masing dari keduanya seratus kali, dan janganlah rasa belas kasihan kepada keduanya mencegah kamu untuk (menjalankan) agama (hukum) Allāh, jika kamu beriman kepada Allāh dan pada hari kemudian; dan hendaklah (pelaksanaan) hukuman mereka disaksikan oleh sebagian orang-orang yang beriman".

Dalam Kamus Bahasa Indonesia disebutkan bahwa pelacuran adalah perihal menjual diri sedangkan pelacur berarti wanita tuna susila (Poerwadarminta, 1983: 351). Jadi pelacuran menunjukkan perbuatannya sedangkan pelacur menunjukkan pada orang yang melakukannya. Dalam hukum pidana Islam tidak memberikan definisi mengenai pelacuran, 
demikian pula dalam Kitab Undang Undang Hukum Pidana (KUHP). Undang Undang Nomor 1 Tahun 1974 tentang Perkawinan menyebutkan bahwa pelacuran sebagai perzinaan, sedangkan perzinaan adalah setiap hubungan kelamin antara pria dan wanita di luar perkawinan yang sah (Siregar, 2015: 1-3).

Dapat dikatakan bahwa pelacuran adalah setiap hubungan kelamin di luar perkawinan yang sah antara pria dengan wanita dan salah satu pihak (pelaku) melakukannya dengan maksud mendapatkan suatu keuntungan materi bagi dirinya atau orang lain atau mendapatkan jasa atas perbuatannya. Kata prostitusi merujuk pada kata keterangan yang berarti wanita tuna susila (WTS). Prostitusi juga dapat diartikan sebagai suatu pekerjaan yang bersifat menyerahkan diri atau menjual jasa kepada umum untuk melakukan perbuatan-perbuatan seksual dengan mendapatkan imbalan sesuai dengan apa yang diperjanjikan sebelumnya. Seseorang yang menjual jasa seksual disebut WTS, yang kini kerap disebut dengan istilah Pekerja Seks Komersial (PSK).

Prostitusi dan komersialisasi seks merupakan perbuatan yang dilarang oleh norma agama. Secara kultural, tidak sedikit para guru ngaji, ustadz dan kyai telah memberikan pencerahan di tengah masyarakat (Wawancara dengan Sa'id Ramadlan, Tokoh Masyarakat Kota Surakarta, 19 Januari 2012). Sebaqgai tugas dan kewajiban para ustadz untuk amr ma'rūfnahī munkar, mereka dengan suka rela dan tak henti-hentinya membimbing dan mengarahkan umat untuk mentaati seluruh perintah Allāh swt dan menjauhi seluruh larangan-Nya. Tetapi bimbingan dan arahan dari para ustadz yang bersifat normatif dan persuasif ini kurang menyentuh realitas sosial utama para pekerja seks tersebut.

Para tokoh agama Kristen (Katholik dan Protestan) juga merasa resah terhadap meningkatnya prostitusi, terutama yang menimpa anakanak yang terjerumus ke dalam dunia hitam (Wawancara dengan Juni Wahjono, Tokoh Agama Khatolik dan Ketua Pansus Perda Nomor 3 Tahun 2006, 19 Januari 2012). Sekalipun dari pihak pemerintah telah mengadakan bimbingan melalui Departemen Sosial, pihak gereja juga memberikan khutbah-khutbah tentang larangan perbuatan dosa, dan mendatangi lokasi-lokasi pelacuran, mengadakan pendekatan, memberikan bimbingan kepada para pekerja seksual komersial.

Upaya yang dilakukan oleh para tokoh masyarakat lintas agama tersebut di atas lebih bersifat persuasif dan pendekatan normatif dengan memberikan bimbingan agama. Berbeda dengan Departemen Sosial yang memberikan penerangan keagamaan dan keterampilan. Secara perorangan dapat disebut nama Abdullah Abdulkadir Assegaf (Wawancara dengan Renny Widayati, Anggota DPRD Kota Surakarta, 21 Januari 2012), ia menyelenggarakan bimbingan keagamaan dan keterampilan serta pinjaman modal kepada para pekerja seks komersial binaannya (Wawancara dengan Abdullah Abdulkadir Assegaf, Tokoh 
Masyarakat dan Anggota DPRD Kota Surakarta, 18 Januari 2012). Berbagai upaya tersebut, ternyata belum cukup efektif menanggulangi maraknya pelacuran di Surakarta.

Terdapat pula kelompok yang menamakan diri Paguyuban Masyarakat Surakarta (PMS), yang anggotanya terdiri atas lintas budaya dan lintas agama, aktif mengadakan penyuluhan kepada masyarakat secara umum dan para pelaku seks komersial. Kegelisahan paguyuban ini, tertuang dalam banyak program seperti sarasehan, diskusi, kegiatan jambore untuk anak-anak dan terutama melalui proses pendidikan (Wawancara dengan Ahmad Zein Solichul Hadi, Kepala Bidang Data dan Pelaporan BAPPEDA Kota Surakarta, 17 Januari 2012). Dalam amatan kelompok ini, para pekerja seks komersial lebih disebabkan tekanan ekonomi, sekalipun ada pula yang sengaja menceburkan diri ke dalam dunia hitam itu. Mereka perlu ditangani secara khusus, di karantina dan diberi pengetahuan dan keterampilan melalui pendidikan.

Berbagai upaya dari elemen masyarakat Kota Surakarta tersebut, dalam beberapa hal mengalami kendala (Wawancara dengan Muhammad Rodli, Anggota DPRD Kota Surakarta, 16 Januari 2012), karena masih adanya elemen masyarakat yang secara ekonomi merasa diuntungkan oleh maraknya prostitusi dan eksploitasi seks komersial. Diantaranya adalah para pengusaha hotel, losmen dan tempat-tempat hiburan yang biasa menyediakan 'hiburan plus', mereka tidak sepakat adanya regulasi dan mengusulkan agar lokalisasi seperti Silir dibuka kembali. Mereka beralasan daripada para pekerja seks komersial tersebut bertebaran di berbagai tempat lebih baik dilokalisasi lagi. (Wawancara dengan Alqaf Hudaya, Tokoh Masyarakat dan Anggota DPRD Kota Surakarta, 19 Januari 2012)

Namun demikian karena masyarakat Kota Surakarta yang mendesak terhadap praktik prostitusidi lokalisasi Silir semakin kuat, maka Pemerintah Kota Surakarta menutup lokalisasi Silir sebagai tempat yang dianggap biang keladi maraknya prostitusi. Tetapi upaya menutup lokalisasi Silir pada tahun 2004 tersebut, justru berdampak tumbuhnya tempat-tempat baru sebagai pusat praktik pelacuran liar yang secara turun-temurun telah ada di beberapa jalan atau lokasi di Kota Surakarta. Seperti di daerah sekitar RRI, alun-alun selatan, Pasar Nangka, Monumen 45, di kafe-kafe, diskotik atau musro, panti pijat dan di salon-salon.

Dapat dikatakan bahwa pelacuran dapat memberi dampak demoralisasi kepada lingkungan khususnya anak-anak remaja dan dapat menjadi sumber penyakit kotor serta penyebab terjadinya abortus serta kematian bayi. Hal yang lebih memperihatinkan adalah apabila penyimpangan tingkah laku yang berlangsung terus menerus, meningkatnya jumlah pelacur dan pengguna, perilaku yang cenderung menyolok dan overacting, akan dapat mendorong terjadinya perubahan 
pandangan dan sikap permisif dan pembenaran dari masyarakat khususnya kalangan generasi muda.

Sekalipun demikian terdapat kelompok masyarakat dissosiatif yaitu masyarakat mengalami konflik batin karena adanya realitas sosial yang bertentangan dengan norma agama (a priori) yang dipegangi oleh masyarakat itu. Kegiatan pelacuran di sekitar rumah mereka tinggal, menjadikan adanya perasaan melawan kenyataan utama dan membuat mereka resah mengingat pengaruh pelacuran terhadap kehidupan sosial melahirkan norma sosial budaya mereka bertentangan dengan keyakinan umat beriman, kata Emile Durkheim (Cabin \& Dortier, 2003: 46).

Kenyataan utama hidup sehari-hari yang telah terintegrasi dan tersosialisasi bagi seseorang atau masyarakat akan dipertahankan sekalipun mesti berhadapan dengankenyataan menyimpang. Deskripsi teori tersebut menjelaskan bahwa lahirnya Peraturan Daerah Nomor 3 tahun 2006 merupakan pelembagaan pranata sosial dalam kehidupan yang berbeda dari kenyataan hidup sehari-hari. Kehadiran pranata sosial diberi status berlainan dengan kenyataan hidup sehari-hari masyarakat sebagai kenyataan utama karena muatan pranata sosial itu didasarkan pada norma agama (syari'ah) sebagai sumber pengetahuan ideal yang melarang kegiatan prostitusi dan eksploitasi seks komersial di tengah masyarakat.

Hadirnya pranata sosial baru, mengantarkan pada suatu kenyataan berbeda yang melampaui batas kehidupan sehari-hari. Suatu pranata yang membatasi kenyataan sehari-hari dan bisa menjadi masalah tersendiri bila tidak mampu diintegrasikan ke dalam kenyataan utama. Proses integrasi bersamaan dengan proses sosialisasi, agar kehadiran pranata sosial yang baru tidak menghadirkan masalah dalam kehidupan sehari-hari. Bila proses integrasi dan sosialisasi tidak bisa berjalan secara alami, maka tidak akan terjadi pergeseran atau perubahan dari kenyataan hidup sehari-hari (Cabin \& Dortier, 2003: 47).

Sebagai contoh ketika Pemerintah Daerah Kota Surakarta membuat Peraturan Daerah Nomor 1 Tahun 1975 tentang Pemberantasan Tunasusila. Oleh karena tidak terjadi proses integrasi dan sosialisasi, maka segala upaya dalam bentuk bimbingan kepada para wanita tunasusila dan pemantapan program rehabilitasi sosial bagi mantan penyandang ketunasusilaan yang dikonstruksi dalam peraturan daerah itu selalu mengalami kegagalan (Departemen Sosial RI, 1984: 23). Bahkan program rehabilitasi dan resosialisasi di Kota Surakarta yang dipusatkan di lokalisasi Silir kemudian disalahgunakan sebagai tempat penampungan perempuan penghibur.

Peraturan Daerah Nomor 1 Tahun 1975 ini melokalisasi praktik prostitusi di suatu tempatyang bernama Silir dengan pertimbangan karena praktik pelacuran secara turun-temurun yang ada di beberapa jalan atau lokasi di Kota Surakartasupaya tidak menjadi liar (Naskah 
Akademik Rancangan Peraturan Daerah Kota Surakarta tentang Prostitusi dan Eksploitasi Seksual Komersial). Tersebarnya praktik prostitusi di beberapa temapt menjadi sangat sulit untuk ditertibkan dan dibina. Oleh karena itu lokalisasi ini dimaksudkan untuk memudahkan pemantauan dan membina mereka ke arah kenyataan utama hidup sehari-hari yang wajar (Wawancara dengan Ahmad Zain Solichul Hadi, Kepala Bidang Data dan Pelaporan BAPPEDA Kota Surakarta, 17 Januari 2012).

Demikian pula, upaya rehabilitasi sosial para wanita tuna susila melalui program yang dilaksanakan unit pelaksana teknis (UPT) Dinas Kesejahteraan Sosial Provinsi Jawa Tengah oleh Panti Karya Wanita Utama Surakarta dimaksudkan untuk mengarahkan mereka ke arah kenyataan utama hidup sehari-hari. Untuk keperluan tersebut jangka waktu pembinaan di dalam panti berlangsung 6-12 bulan dengan mendapatkan bimbingan fisik, mental, sosial dan keterampilan sehingga diharapkan mereka dapat menjalani kehidupan baruberdasarkan norma utama. Pembinaan dilakukan dengan dua macam sistem. Pertama, sistem panti yang mengharuskan peserta binaan tetap tinggal di asrama, mereka tidak boleh melakukan praktik pelayanan seks. Kedua, sistem resosialisasi yang lebih longgar, para peserta binaan datang sekali watu, tetapi mereka tinggal dalam lokalisasi dan masih diperbolehkan memberikan pelayanan kepada para tamu.

Deskripsi tersebut di atas menunjukkan bahwa masalah pelacuran memiliki kompleksitas baik secara sosial, agama, ekonomi, hukum, kesehatan maupun hak asasi manusia yang tidak mudah diselesaikan secara persuasif. Istilah lokalisasi diganti dengan resosialisasi dengankonsekuensi perlakuan yang mengarah kepada normalisasi dan refungsionalisasi wanita tunasusila dalam kehidupan masyarakat dibebankan kepada pemerintah daerah. Selanjutnya pemberian bimbingan fisik, mental, sosial dan keterampilan sebagai perwujudan dari adanya normalisasi fungsi sosial para wanita tuna susila tersebut diambil alih Pemerintah Daerah.

Menyadari kompleksitas masalah pelacuran, pemerintah melalui Departemen Sosial merumuskan suatu kebijakan untuk mengatasi masalah pelacuran secara berkelanjutan dalam bentuk pembinaan dan pemberian keterampilan para pekerja seks komersial. Bentuk kebijakan ini diarahkan pada upaya tindak lanjut, peningkatan, perluasan, dan penanganan permasalahan ketunasusilaan serta arahan dan bimbingan kepada para pekerja seks komersial yang dilakukan dengan mengambil langkah berupa pemantapan program rehabilitasi sosial dan resosialisasi bagi mantan penyandang ketunasusilaan yang didirikan di berbagai tempat.

Program pemerintah melalui Departemen Sosial ini khususnya kepada para kurban prostitusi dan seks komersial masih bersifat persuasif dalam bentuk arahan dan bimbingan, tetapi kepada para perempuan 
pekerja seks komersial mengambil langkahlebih tegas. Program ini ternyata tidak cukup efektif karena hanya menyertakan subyek pekerja seks perempuan. Sementara yang laki-laki tidak atau jarang mendapatkan pengarahan dan bimbingan (Renny Widayawati, Wawancara, 28 Januari 2012). Bukti kurang efektifnya program arahan dan bimbingan ini adalah bahwa para perempuan pekerja seks akan hadir ketika diminta mengikuti arahan dan bimbingan, tetapi pada saat telah selesai mengikuti program tersebut, mereka kembali ke tempat kerja semula (Wawancara dengan Ahmad Zain Solichul Hadi, Kepala Bidang Data dan Pelaporan BAPPEDA Kota Surakarta, 17 Januari 2012).

Dalam kerangka lebih meningkatkan efektifitas program pemerintah Kota Surakarta mempertimbangkan payung hukum sebagai landasan yuridis dalam penanganan masalah prostitusi yang lebih komprehensif dan memiliki daya paksa yang sah (represif). Sebab Peraturan Daerah Nomor 1 Tahun 1975 tentang Pemberantasan Tunasusila sudah tidak efektif lagi, bias gender dan tidak dapat menjangkau seluruh pihak yang terlibat dalam industri seks yang marak di Kota Surakarta. Perda ini juga melokalisasi pelacuran yangmenjadi sorotan publik dan pemerintah dianggap melagalisasikan prostitusi.

Oleh karena berbagai hal tersebut di atas, desakan dari masyarakat semakin kuat agar lokalisasi Silir ditutup,disamping bisa mengurangi citra Kota Surakarta juga karena telah dirasakan lebih besar madaratnya.Sebelum tahun 1998 tuntutantersebut datang dari berbagai elemen anggota DPRD Kota Surakarta, dari generasi muda dan mahasiswa KAMMI, HMI dan MUDIKA (muda-mudi Kristiani) menyatu dalam kegiatan lintas agama, secara bersama-sama melakukan demo agar lokalisasi Silir ditutup (Wawancara dengan Ahmad Zein Solichul Hadi, Kepala Bidang Data dan Pelaporan BAPPEDA Kota Surakarta, 17 Januari 2012). Dari berbagai kelompok keagamaan kompak agar lokalisasi Silir dibubarkan, karena telah merusak moral masyarakat dan menganggap pemerintah melegalisasi perzinaan.

Tuntutan dan desakan dari berbagai elemen masyarakat tersebut menunjukkan bahwa penanggulangan maraknya prostitusi dan eksploitasi seks komersial tidak bisa diselesaikan dengan pranata sosial yang bersifat persuasif. Menyadari keadaan tersebut Pemerintah Daerah merespon dengan merumuskan peraturan daerah yang lebih komprehensif dan represif. Ketika menyampaikan nota penjelasan dalam rangka pembahasan rancangan peraturan daerah tentang eksploitasi seksual komersial, Walikota Surakarta menyatakan bahwa perkembangan praktik prostitusi dan pola-pola pelayanannya telah menimbulkan peningkatan penyakit menular seksual di masyarakat, dan merusak mentalitas masyarakat, terutama dari kalangan generasi muda yang rentan terhadap ekses negatif dari adanya praktik. 
Walikota Surakarta dalam pengantar Rapat Paripurna Dewan Perwakilan Rakyat Daerah Kota Surakarta juga meyatakan bahwa kegiatan eksploitasi seks komersial, selain bertentangan dengan normanorma agama dan sosial juga merupakan kejahatan berat terhadap kemanusiaan yang sangat merisaukan. Para korban dari kegiatan maksiat itu terdiri dari kaum lemah, yakni anak-anak dan perempuan. Bentuk dan mekanisme serta pola pelayanan yang ditawarkan semakin beragam dansebagian masyarakat sengaja membangun lokasi-lokasi prostitusi baik terselubung maupun terang-terangan, baik terorganisir maupun liar, yang disediakan bagi pelanggan-pelanggannya (Walikota Surakarta, 2006: 2).

Dari keseluruhan data tentang maraknya prostitusi beserta dampak yang ditimbulkan, upaya-upaya yang telah dilakukan masyarakat untuk menanggulanginya, merupakan kenyataan sosial dalam kehidupan masyarakat. Kenyataan sosial masyarakat Kota Surakarta berupa semesta kecil (labenswelt), rumit dan lengkap, terdiri atas lingkungan fisik, lingkungan sosial, interaksi antar manusia (inter subyektivitas) dan nilainilai agama yang dihayati.

Untuk menyelesaikan masalah yang dihadapi masyarakat Kota Surakarta sebagai semesta kecil tersebut, pemerintah mengkonstruksi peraturan daerah yang komprehensifsesunguhnya bukan sekedar untuk menanggulangi maraknya prostitusi dan eksploitasi seks komersial, tetapi juga merupakan upaya membangun dunianya sendiri yang disebut masyarakat. Hal demikian berarti masyarakat Kota Surakarta sedang membangun dialektika antara aktivitas individu-individu dengan konteks masalah yang sedang dihadapi bersama, yaitu menanggulangi maraknya prostitusi dan eksploitasi seks komersial beserta dampak yang ditimbulkan.

Menilik karakteristik keberagamaan masyarakat Kota Surakarta dan besarnya tantangan yang dihadapi dalam menanggulangi maraknya prostitusi dan eksploitasi seks komersial, dibutuhkan pranata yang memiliki legitimasi sosial dan religius dan sekaligus legitimasi yuridis. Pranata sosial berupa Peraturan Daerah Kota Surakarta Nomor 3 Tahun 2006 tentang Penanggulangan Eksploitasi Seksual Komersial merupakan paranata yang memiliki ketiga legitimasi tersebut dan merupakan upaya membangun dunianya sendiri, dunia masyarakat Kota Surakarta.

Peraturan Daerah Kota Surakarta Nomor 3 Tahun 2006 tersebut diobyektivasi dari pengalaman sosio-religius dan diterima masyarakat untuk menanggulangi maraknya prostitusi dan eksploitasi seks komersial di Kota Surakarta berarti telah mendapatkan legitimasi. Namun demikian hadirnya Perda tersebut masih harus disertai upaya integrasi dan sosialisasi untuk mengatasi besarnya kerawanan (subyektivitas) individu dan kelompok sosial masyarakat sebagai perlawanan dan pembangkangan terhadap tatanan sosial itu. Oleh karena itu diperlukan legitimasi tambahan yaitu legitimasi yuridis sebagai penyangga kedua 
legitimasi yang sudah ada dan untuk melegitimasi pemaksaan kepada para pembangkang terhadap tatanan sosial itu.

Legitimasi tambahan dalam konstruksi Peraturan Daerah Kota Surakarta Nomor 3 tahun 2006 telah diperoleh melalui prosedur legitimasi yuridis. Dengan demikian peraturan daerah ini relevan dengan penerapan hukum Islam dan signifikan memberikan legitimasi kepada pemerintah untuk mengatasi besarnya perlawanan dan pembangkangan, dan melegitimasi tindakan para penegak hukum dalam menindak para pembangkang terhadap tatanan sosial obyektif itu.

Penerapan hukum Islam secara formal (menjadi peraturan daerah) di Kota Surakarta, mendapatkan signifikansi karena kondisi sosio-religio dan kultur masyarakat dalam menghadapi besarnya kerawanan (subyektivitas) individu dan kelompok sosial masyarakat sebagai perlawanan dan pembangkangan terhadap tatanan sosial yang telah memperoleh legitimasi sosiologis dan religius. Dengan legitimasi yuridis, maka peraturan daerah itu sekaligus mendapatkan legitimasi kognitif dan legitimasi normatif.

Status legitimasi kognitif memberikan kesahihan atas muatan pengetahuan dan makna-makna yang sudah diobyektivasi peraturan daerah itu, dan status legitimasi normatif membenarkan tatanan kelembagaan. Dengan status legitimasi kognitif dan legitimasi normatif pada peraturan daerah ini, maka perintah dan larangan yang bersifat praktis mendapatkan pengakuan yang absah baik secara sosiologis maupun yuridis.

\section{SIMPULAN}

Hasil penelitian ini menunjukkan bahwa pemberlakuan syariah Islam di Indonesia sangat bergantung karakteristik keberagamaan masyarakatnya. Menilik karakteristik keberagamaan masyarakat Kota Surakarta dan besarnya tantangan yang dihadapi dalam menanggulangi maraknya prostitusi dan eksploitasi seks komersial, dibutuhkan pranata yang memiliki legitimasi sosial dan religius dan sekaligus legitimasi yuridis.

Legitimasi yuridis sebagai penyangga kedua legitimasi yang sudah ada (sosial dan religious) dimaksudkan juga untuk melegitimasi pemaksaan kepada para pembangkang terhadap tatanan sosial itu. Peraturan Daerah Kota Surakarta Nomor 3 Tahun 2006 tentang Penanggulangan Eksploitasi Seksual Komersial ini sekalipun tidak menyebut kata syari'ah tetapi substansi materi yang diatur dalam perda tersebut sepenuhnya materi syari'ah atau fiqh. Hadirnya Perda tersebut masih harus disertai upaya integrasi dan sosialisasi untuk mengatasi 
Pemberlakuan Perda Syari'ah dalam Perspektif....

besarnya kerawanan (subyektivitas) individu dan kelompok sosial masyarakat sebagai perlawanan dan pembangkangan terhadap tatanan sosial itu.

\section{DAFTAR PUSTAKA}

\section{Buku-buku}

Abdullah, M. Amin, Studi Agama-Normativitas atau Historisitas, Yogyakarta: Pustaka Pelajar, 1996.

al-Ghazālī, Al-Imām Ab̄̄ Hāmid Muhammad bin Miuhammad, AlMustafā fí 'Ilm al-Uul, Beirut: Dār al-Kutub al-'Ilmiyah, 2000.

Berger, Peter L. dan Thomas Luckmann, Tafsir Sosial atas Kenyataan, Jakarta: LP3ES, 1990.

Berger, Peter L., Langit Suci - Agama Sebagai Realitas Sosial, Jakarta: LP3ES, Cet. Ke-2, 1994.

Berger, Peter L. "Problema dan Agenda" dalam Sisi Lain Tuhan (The Other Side of God)-Polaritas dalam Agama Agama Dunia, Yogyakarta: Qirtas, Cet. Ke- 1, 2003.

Departemen Agama RI, al-Quran dan Terjemahny

Giddiens, Anthony (et.al), Sosiologi - Sejarah dan Berbegai Pemikirannya, Yogyakarta: Kreasi Wacana, Cet. Ke-3, 2008.

Hendropuspito, D., Sosiologi Agama, Yogyakarta: Kanisius, Cet. Ke-16, 2000.

Irwanto, Muhammad Farid dan Jeffry Anwar, Anak yang Membutuhkan Perlindungan Khusus di Indnesia: Analisis Situasi, Jakarta: Departemen Sosial dan UNICEF, Kerjasama PKPM Unika Atmajaya Jakarta, 1999.

Iqbal, Muhammad.,The Reconstruction of Religious Thought in Islam Lahore: Muhammad Ashraf, 1962.

Kadir, Muslim A., Dasar-Dasar Praktikum Keberagamaan Dalam Islam, Yogyakarta, Pustaka Pelajar, Cet. Ke-1, 2011.

Mohammad Muslih, Filsafat Ilmu Kajian atas Asumsi Dasar Paradigma dan Kerangka Teori Ilmu Pengetahuan, Yogyakarta: Belukar, Cet. Ke-1, 2004

Nur Syam, Islam Pesisir, Yogyakarta: LKiS, Cet. Ke-1, 2005.

Noeng Muhadjir, Metodologi Keilmuan Telaah Sistematis Fungsional Komparatif, Yogyakarta: Rake Sarasin, 1998.

Poespoprodjo, W., Logika Scientifika Pengantar Dialektika dan Ilmu, Bandung: Pustaka Grafika, Cet. Ke-1, 1999.

Poerwadarminta, W.J.S, Kamus Umum Bahasa Indonesia, Jakarta : Balai Pustaka, 1983. 
Rahardjo, Satjipto, Ilmu Hukum, Bandung: Citra Aditya Bakti, Cet.ke.4, 1996.

Riyanto, Geger, Peter L. Berger., Perspektif Metateori Pemikiran, Jakarta: LP3ES, Cet. Ke-1, 2009.

Ritzer, George, dan Douglas J. Goodman, Modern sociological Theory, 6th Edition, alih bahasa oleh Alimandan dengan judul "Teori Sosiologi Modern", Edisi ke 6, Jakarta: Prenada Media Group, Cet. Ke. 5, 2008.

Suyanto, Bagong dan Sri Sanituti Hariadi, Crisis and Child Abuse, Surabaya: Airlangga University Press, 2002.

Tafsir, Ahmad., Filsafat Umum: Akal dan Hati Sejak Thales Sampai James, Bandung: Remaja Rosdakarya, Cet. Ke-2, 1992.

Tāhir bin' shūr, Al-Imam Muhammad, Maqasid al-Sharī'ah al-Islāmiyah, hlm. 49. Bandingkan dengan pendapat al- Shātibī dalam AlMuwāfaqāt fī Ușūl al-Shari'ah, I, 2002.

Zeitlin, Irving M., Memahami Kembali Sosiologi-Kritik terhadapTeori sosiologi Kontemporer, Yogyakarta: Gajah Mada University Press, 1998.

\section{Jurnal-jurnal}

Amalia, Journal of Legal, Ethical and Regulatory, Issues Volume 21, (Special Issue, 2018).

Binahayati Rusyidi, Nunung Nurwati, Penanganan Pekerja Seks Komersial di Indonesia, Prosiding Penelitian \& Pengabdian Kepada Masyaraka, eISSN : 2581-1126 p ISSN : 2442-448X, Vol 5, No: 3, Desember 2018

Dialmy, Abdessamad (2010), Sexuality and Islam, The European Journal of Contraception and Reproductive Health Care, June 2010.

Dortier, Jean Francois., tentang "Max Weber Sosiolog Modernitas" dalam Philippe Cabin \& Jean Francois Dortier (ed), Sosiologi - Sejarah dan Berbegai Pemikirannya, alih bahasa Ninik Rochani Sjams, Yogyakarta, Kreasi Wacana, 2008.

Ferguson L, Gruskin S, (2009).Government regulation of sex and sexuality: in their own words.Reprod Health Matters. Nov;17(34):108-18. doi: 10.1016/S0968-8080 (09) 34483-3.

Gruskin S, Ferguson L (2009). Government regulation of sex and sexuality: in their own words.Reprod Health Matters. Nov;17(34):108-18. doi: 10.1016/S0968-8080(09)34483-3.

Hamdan, Dampak Prostitusi Liar Terhadap Kehidupan Sosial Masyarakat Desa Sekolaq Muliaq, Kecamatan Sekolaq Darat, Kabupaten Kutai Barat, PSIKOSTUDIA, Jurnal Psikologi - Prodi Psikologi Fisipol Universitas Mulawarman, Vol 1, No 2, 2012. 
Hiadayat, Deddy, Paradigma dan Perkembangan Penelitian Komunikasi dalam Jurnal Ikatan Sarjana Komunikasi Indonesia,Vol. III., Jakarta: IKSI dan ROSDA, 1999.

Ikhuanza, Rahmannur, Journal Equitable, ISSN: 2541-7037 e-ISSN: 26142643, Vol. 2 No. 2 (November 2017).

Jatmikowati, S. H. (2019). Perception Against the Activity of Commercial Sex Workers in Slorok Village. Mediterranean Journal of Social Sciences, 10(6), 76.

Jatmikowati, S. H. (2015). Driving Factors and Their Characteristics of Prostitutes in Indonesia: A Phenomenology Approach. Mediterranean Journal of Social Sciences. doi:10.5901/mjss.2015.v6n6s1.

Joni, Dewa Ayu S, Dewi Pascarani, Ni Nyoman, Tedi Erviantono, Interaksionisme Simbolik Aparatus Dan Pekerja Seks Di Bali, dalamJISoP - Jurnal Ilmu Sosial dan Politik, Vol. 1 No. 2 (Oktober 2019).

Juliastuti, Diyah, Lisa Fitzgerald(2020),Sexual and reproductive health of women living with HIV in Muslim-majority countries: a systematic mixed studies review, BMC International Health and Human Rights 20(1), DOI: 10.1186/s12914-020-00225-z

Lee, Samuel and Persson, Petra, Human Trafficking and Regulating Prostitution (November 1, 2018). IFN Working Paper No. 996; NYU Stern School of Business EC-12-07; NYU Law and Economics Research Paper No. 12-08. Available at SSRN: https:/ / ssrn.com/abstract=2057299 or http:/ / dx.doi.org/10.2 139/ssrn.2057299

Mia Amalia (2018), Criminal Law Policy to Foreign Prostitution in the Puncak Area in Refrigeration Criminal Law, Journal of Legal, Ethical and Regulatory, Issues Volume 21, (Special Issue, 2018).

Post, C., Brouwer, J.G. \& Vols, M. (2019) Regulation of Prostitution in the Netherlands: Liberal Dream or Growing Repression? Eur J Crim Policy Res 25, 99-118 (2019). https://doi.org/10.1007/s10610-0189371-8.

Rahmannur Ikhuanza (2017). Perlindungan Hukum Terhadap Kurban Perdagangan Seks Komersial di Kota Pakanbaru, Journal Equitable. Vol. 2 No. 2 November 2017.

Zainal, Humairah (2018): The irony of Islamization: sexuality, piety and power on Malaysian screens, Continuum, doi: 10.1080/10304312.2018.1536778.

\section{Peraturan Perundang-Undangan}


Mudzakir

Lembaran Daerah Kota Surakarta Tahun 2006 Nomor 3 Seri E Nomor 1 tentang Peraturan Daerah Kota Surakarta Nomor 3 tahun 2006 tentang Penanggulangan Eksploitasi Seksual Komersial. 